\title{
Spatiotemporal Trend Analysis of the Mean Annual Rainfall in Senegal
}

\section{Lamine Diop}

UFR S2ATA « Sciences Agronomiques, de l'Aquaculture et des Technologies Alimentaires », Université Gaston Berger (UGB) Saint Louis, Sénégal

Department of Food, Agricultural and Biological Engineering, The Ohio State University, Columbus, OH, USA

\section{Ansoumana Bodian}

Laboratoire Leïdi « Dynamique des territoires et développement » Université Gaston Berger (UGB) Saint Louis, Sénégal

\section{Dior Diallo}

Département Génie Rural, Ecole Nationale Supérieure d’Agriculture (ENSA), Université de Thiès (UT), Thiès, Sénégal

doi: 10.19044/esj.2016.v12n12p231 URL:http://dx.doi.org/10.19044/esj.2016.v12n12p231

\section{Abstract}

The spatiotemporal trends of annual rainfall in Senegal during 1940 2013 were investigated using the Mann-Kendall test and Theil-Sen's slope estimator. Theil and Sen's slope estimator test was used for finding the magnitude of change over a time period. Inverse Weight Distance (IDW) technique in Arc GIS 10.2 was used to investigate spatial patterns of the trends over the entire country. For the period 1940-2013, the results of the analysis showed negative trends in annual rainfall at the whole country except for the Bakel station which exhibits a positive trend but not significant. While for the period 1984 - 2013, all the stations show a positive trend with 07 out of 22 stations exhibiting a significant trend at the $95 \%$ confidence interval. The spatial distribution of trend during the period 19402013 showed a significant negative trend in the whole study of area except small areas located at the extreme South Est and West as well as North East and West. The trend magnitude varies between $-4.41 \mathrm{~mm} /$ year to $1.34 \mathrm{~mm}$ for the period 1940-2013 with a maximum negative magnitude at the Tambacounda station. For 1984-2013, the trend magnitude is positive for the whole country with values varying between $2.67 \mathrm{~mm} /$ year at Goudiry and $12.2 \mathrm{~mm} /$ year at Ziguinchor. Magnitudes are greater than $5 \mathrm{~mm} /$ year, for stations with significant positive trend. 
Keywords: Mann-Kendall, rainfall, Sen Slope estimator, Senegal

\section{Introduction}

Water resource has become a prime concern for any development and planning including food production, flood control and effective water resource management (Mondal et al., 2012). Therefore, any parameters that influence it must be carefully study and evaluate.

Rainfall is one of the key climatic variables that affect both the spatial and temporal patterns of water availability (Hasan et al., 2014, Taxak et al., 2014). That is why the importance of investigating long-term trends and variability of hydro-climatic variables is becoming crucial for sustainable water resources management in different parts of the world (Tabari et al., 2015) and agriculture (Mercy, 2015). Haigh (2014) highlighted that analysis of rainfall trend is important in studying the impacts of climate change for water resources planning and management.

Due to the importance of rainfall on social, economic and environmental issues, several studies were focusing on its analysis in Western Africa (Sircoulon, 1976; Servat et al., 1999; Bodian, 2011; Bodian, 2014; Bodian et al., 2016). Indeed, the rainfall is the most determining climatic variable for the life of the populations (Ali, 2010). From these studies, many authors (Lamb P, 1982; Carbonnel and Hubert, 1985; Nicholson, 1986; Hubert and Carbonnel, 1987; Hubert et al., on 1988; Paturel and al., 1998; Servat et al., 1999; Nicholson et al., 1999; L'Hôte et al., 2002; Niel et al., 2005) showed a decreasing of annual rainfall since the end of the 60s and the beginning of 1970s. This rainfall reduction led to the decrease of water resources (Hubert et al., 2007; Abrate et al., 2013), the modification of the natural ecosystems and the socioeconomic systems (Liénou, 2007).

Recently, it has been noticed that rainy seasons are becoming wetter and wetter. Thus, some authors (Sene and Ozer, 2002; Ozer et al., 2003) pointed out that this fact may be a sign towards a progressive return on more favorable rainfall conditions. Therefore, it is interested to extensively evaluate this assertion from those authors in local condition. Bodian (2014), based on the amount of rainfall, classified three periods over the Senegal: (i) wetted periods during 1940-1969; (ii) 1970-1998 characterized by dried seasons; (iii) and the retour of wetted periods during $1999-2013$. He used mainly the standardized annual rainfall and change point test to carry out his analysis. However, he did not look for any trend analysis in his study. Furthermore, a series of 14 years of data (1999 - 2013) are not very consistent to carry out statistical analysis. Therefore, this paper seeks to complete and extend the research from Bodian (2014). 
The purpose of this paper is to analyze the spatiotemporal variability of annual rainfall in Senegal during 1940-2013. These include: (i) analysis and discussion of trend characteristics of rainfall; (ii) quantification of the significance change by using Man-Kendall test and determination of trend magnitude and the slope of precipitation trends using the non-parametric Sen's slope approach.

\section{Material and methods}

\section{Data and Study area}

Annual rainfall data are monitored at 22 meteorological stations from 1940 to 2013 across Senegal by the Senegal National Meteorology Agency (ANACIM). The spatial distribution of stations under this study is presented in Figure 1. Senegal is located in West Africa under a semiarid Sahelian climate and has a total area of $196,722 \mathrm{Km}^{2}$ with generally flat and low-lying landscape. Its plains rise to form foothills in the south-eastern part of the country along the border with Guinea-Bissau. In contrast, the northern part of the country is extremely dry, semi-arid terrain with sparse vegetation scattered sporadically (UNEP, 2015).

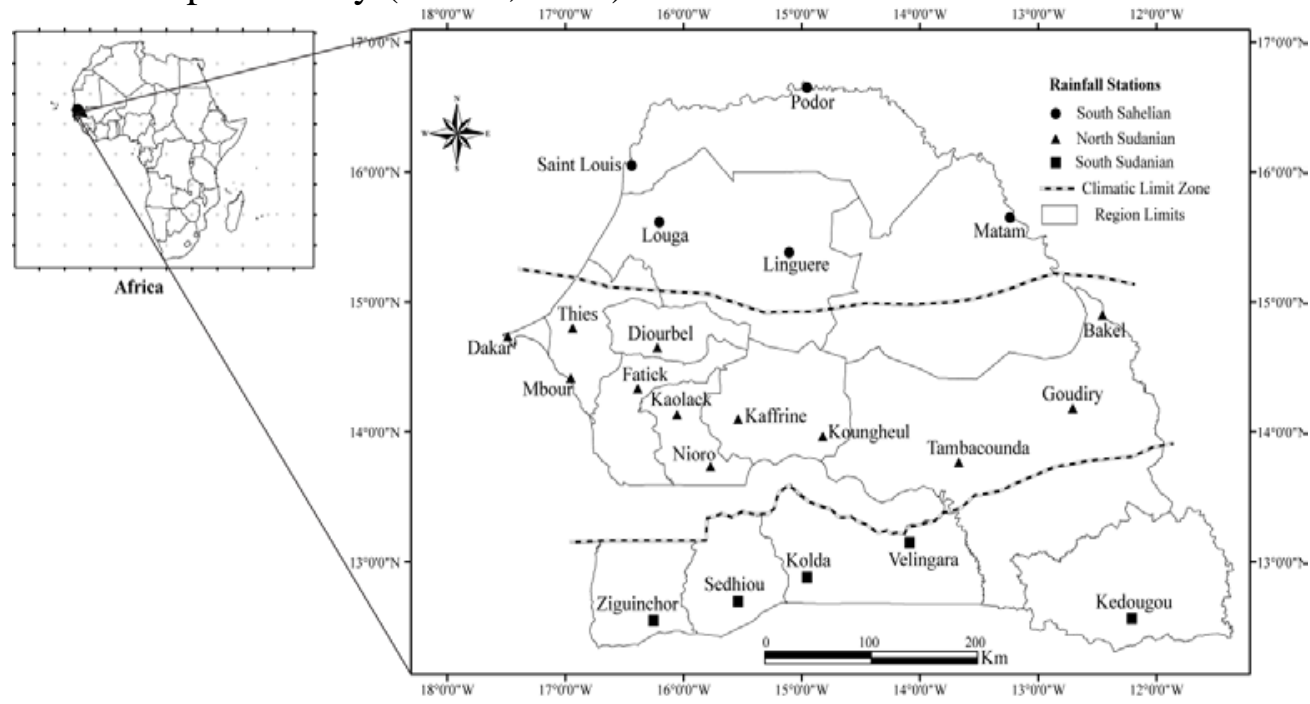

Figure 1: Spatial distribution of the rain gauge stations

Table 1 gives the list of stations selected for this study as well as some statistics for each of them. 
Table 1: Locations of station and some statistics

\begin{tabular}{lllllll}
\hline & $\begin{array}{l}\text { Latitude } \\
\text { Station Name }\end{array}$ & $\begin{array}{l}\text { Longitude } \\
\text { (ócimal) }\end{array}$ & $\begin{array}{l}\text { ( décimal }) \\
(\mathrm{m})\end{array}$ & $\begin{array}{l}\text { Mean } \\
(\mathrm{mm})\end{array}$ & $\begin{array}{l}\text { Standard } \\
\text { Deviation } \\
(\mathrm{mm})\end{array}$ & $\begin{array}{l}\text { Coefficient } \\
\text { of variation (\%) }\end{array}$ \\
\hline Bakel & 14,90 & $-12,47$ & 25 & 515 & 133 & 26 \\
Dakar & 14,73 & $-17,50$ & 27 & 449 & 179 & 40 \\
Diourbel & 14,65 & $-16,23$ & 7 & 549 & 179 & 33 \\
Fatick & 14,33 & $-16,40$ & 6 & 638 & 213 & 33 \\
Goudiry & 14,18 & $-12,72$ & 59 & 674 & 142 & 21 \\
Kaffrine & 14,10 & $-15,55$ & 11 & 655 & 167 & 26 \\
Kaolack & 14,13 & $-16,07$ & 6 & 655 & 184 & 28 \\
Kedougou & 12,57 & $-12,22$ & 178 & 1206 & 220 & 18 \\
Kolda & 12,88 & $-14,97$ & 35 & 1109 & 260 & 23 \\
Koungheul & 13,97 & $-14,83$ & 11 & 766 & 198 & 26 \\
Linguere & 15,38 & $-15,12$ & 20 & 420 & 130 & 31 \\
Louga & 15,62 & $-16,22$ & 38 & 352 & 149 & 42 \\
Matam & 15,65 & $-13,25$ & 15 & 402 & 130 & 32 \\
Mbour & 14,42 & $-16,97$ & 10 & 587 & 239 & 41 \\
Nioro & 13,73 & $-15,78$ & 18 & 803 & 209 & 26 \\
Podor & 16,65 & $-14,97$ & 6 & 247 & 109 & 44 \\
Saint Louis & 16,05 & $-16,45$ & 4 & 281 & 109 & 39 \\
Sedhiou & 12,70 & $-15,55$ & 15 & 1191 & 273 & 23 \\
Tambacounda & 13,77 & $-13,68$ & 49 & 775 & 194 & 25 \\
Thies & 14,80 & $-16,95$ & 71 & 526 & 191 & 36 \\
Velingara & 13,15 & $-14,10$ & 38 & 944 & 211 & 22 \\
Ziguinchor & 12,55 & $-16,27$ & 26 & 1325 & 291 & 22 \\
\hline
\end{tabular}

\section{Trend analysis}

Two non-parametric methods (Mann-Kendall and Sen's slope estimator) were used to detect the annual rainfall trends over the entire Senegal. One of the advantages of non-parametric trend tests is that it does not require data to be normally distributed. It just needs data to be independent.

\section{Mann-Kendall test}

The Mann-Kendall (MK) test is one of the most important statistical methods commonly used for detecting a trend in hydroclimatic time series (Tabari et al, 2015). It has been widely used in long-term trend analysis of climatic and hydrologic time series (Zhang et al. 2010; Tabari et al., 2011; Marofi et al., 2011; Du et al., 2013; Golian et al., 2014.; Gocic and Trajkovic 2014, Tabari et al., 2015). The mathematical equations for calculating MannKendall Statistics S, Var (S), and standardized test statistics Z are as follows:

$$
S=\sum_{\mathrm{k}=1}^{\mathrm{n}-1} \sum_{\mathrm{j}=\mathrm{k}+1}^{\mathrm{n}} \operatorname{sign}\left(\mathrm{x}_{\mathrm{j}}-\mathrm{x}_{\mathrm{k}}\right)
$$




$$
\begin{gathered}
\operatorname{sign}\left(x_{j}-x_{k}\right)=\left\{\begin{array}{c}
+1 \text { if }\left(x_{j}-x_{k}>0\right. \\
0 \text { if }\left(x_{j}-x_{k}\right)=0 \\
-1 \text { if }\left(x_{j}-x_{k}<0\right.
\end{array}\right. \\
\operatorname{Var}(S)=\frac{\left[[n(n-1)(2 n+5)]-\sum_{i=1}^{n} t_{i}\left(t_{i}-1\right)\left(2 t_{i}+5\right)\right]}{18}
\end{gathered}
$$

Where $n$ is the number of data points, $t_{i}$ is the number of ties for the $i$ value, and $\mathrm{m}$ is the number of tied values. For $\mathrm{n}>10$, the test statistic $\mathrm{Z}$ approximately follows a standard normal distribution:

$$
Z=\left\{\begin{array}{l}
\frac{S-1}{\sqrt{\operatorname{Var}(S)}} \text { if } S>0 \\
0 \text { if } S>0 \\
\frac{S+1}{\sqrt{\operatorname{Var}(S)}} \text { if } S<0
\end{array}\right.
$$

A positive value of $\mathrm{Z}$ indicates an increasing trend and a negative value indicate a decreasing trend. The null hypothesis Ho: there is no significant trend of the annual rainfall is reject at $5 \%$ if $|\mathrm{Z}|>1.96$.

If the series is auto correlated, the variance has to be modified by the equation 5

$$
\operatorname{Var} *(\mathrm{~S})=\operatorname{Var}(\mathrm{S}) \cdot \frac{\mathrm{n}}{\mathrm{n} *}
$$

Where $\operatorname{Var} *(\mathrm{~S})$ is the modified variance, $\operatorname{Var}(\mathrm{S})$ is the variance of Mann-Kendall before the modification, $\mathrm{n}$ is the actual sample size of the sample data and $\mathrm{n} *$ is the effective sample size.

$$
n *=\frac{n}{1+2 \sum_{k=1}^{n-1}\left(1-\frac{k}{n}\right) \cdot r_{k}}
$$

Where $r_{k}$ is the significant lag-k serial correlation coefficient given by the equation (7)

$$
\begin{gathered}
r_{k}=\frac{\frac{1}{n-k} \sum_{t=1}^{n-k}\left[X_{t}-\left(\frac{1}{n} \sum_{t=1}^{n} X_{t}\right]\left[X_{t+k}-\left(\frac{1}{n} \sum_{t=1}^{n} X_{t}\right]\right.\right.}{\frac{1}{n} \sum_{t=1}^{n}\left[X_{t}-\left(\frac{1}{n} \sum_{t=1}^{n} X_{t}\right)\right]^{2}} \\
Z c=\left\{\begin{array}{l}
\frac{S-1}{\sqrt{\operatorname{Var} *(S)}} \text { if } S>0 \\
0 \text { if } S>0 \\
\frac{S+1}{\sqrt{\operatorname{Var} *(S)}} \text { if } S<0
\end{array}\right.
\end{gathered}
$$

\section{Theil-Sen's slope}

The slope of $n$ pairs of data points was estimated by using TheilSen's estimator. The slope calculated by Theil-Sen's estimator is a robust 
estimate of the magnitude of a trend (Yue et al., 2002; Tabari et al., 2015). The trend magnitude is estimated as follows.

$$
B=\operatorname{median} \frac{x_{j}-x_{i}}{t_{j}-t_{i}}
$$

Where $x_{j}$ and $x_{i}$ are values at times $t_{j}$ and $t_{i}$ respectively.

\section{Relative Change}

The Relative Change (RC) is computed as follows:

$$
R_{C}=\frac{n \times \beta}{|x|}(10)
$$

Where $\mathrm{n}$ is the length of trend period, $\beta$ is the magnitude of the trend slope of the time series (Sen's slope), and $|x|$ is the absolute average value of the time series.

\section{Spatial Analysis}

Inverse Weight Distance (IWD) (Shepard, 1968) was employed to determine the spatial pattern of annual rainfall, the coefficient of variation, the $\mathrm{Z}$ statistics as well as the relative change of annual rainfall. The software Arc GIS 10.2 was used to carry out this analysis. IWD interpolation determines cell values using a linearly weighted combination of a set of sample points. The weight is inversely proportional to the distance between the observations and the interpolated location. The surface being interpolated should be that of a locational dependent variable.

\section{Resultats and discussion}

\section{Statistical characteristics of annual rainfall}

The results indicated that mean annual rainfall varied from $214 \mathrm{~mm}$ at the station of Podor in the Northern part of Senegal to 1,325 mm at the station of Ziguinchor in the Southern part with a coefficient of variation of $44 \%$ and 22\%, respectively (Table 1). The distribution of the annual rainfall (figure 2a) showed strong gradients, with higher values corresponding to the south of the country and the lower values obtained in the North part of Senegal. These results confirmed those of Fall et al. (2006) who pointed out the north-south gradient in the rainfall pattern in Senegal. 

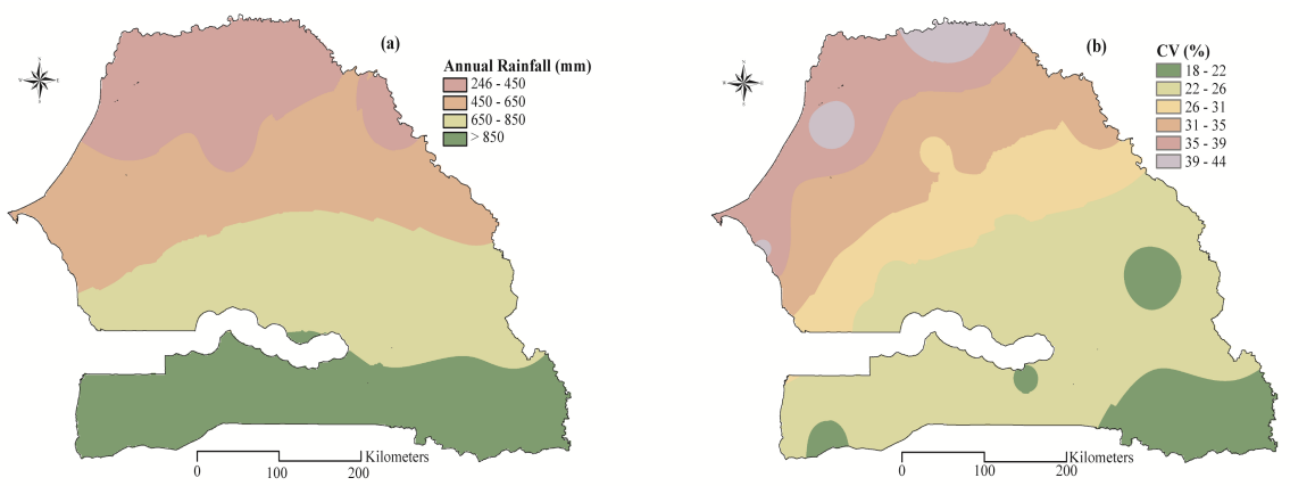

Figure 2: Annual rainfall distribution (a) and coefficient of variation distribution (b) in Senegal (1940-2013)

The Coefficient of Variation (CV), in the inverse manner, exhibits gradients, with higher and lower values in the northern and southern part, respectively (figure $2 \mathrm{~b}$ ). These results point out that the regions with greater rainfall have less variability than the regions with relatively lower rainfall. This fact is confirmed by several authors (Gajbhiye et al., 2015) who demonstrated the same tendency in India.

\section{Trend analysis}

The analysis focused on the long term annual rainfall trend (19402013) as well as on the last thirty years of annual rainfall time series (19842013). Prior to any time series analysis, it is crucial to consider its serial structural. The results of the auto correlation analysis for the period 19402013 are presented in figure 3. Statistically, some annual series were autocorrelated at 5\% significance level at least at lag 1 . These stations are Goudiry, Tambacounda, Thies, Louga, Matam, and Kaolack. The existence of significant serial correlations in the rainfall time series necessitates the removal of the effect of the serial correlations in the trend tests. Therefore, this analysis, presented only the value of $\mathrm{Z}$ statistics values after the removal of serial correlation. 

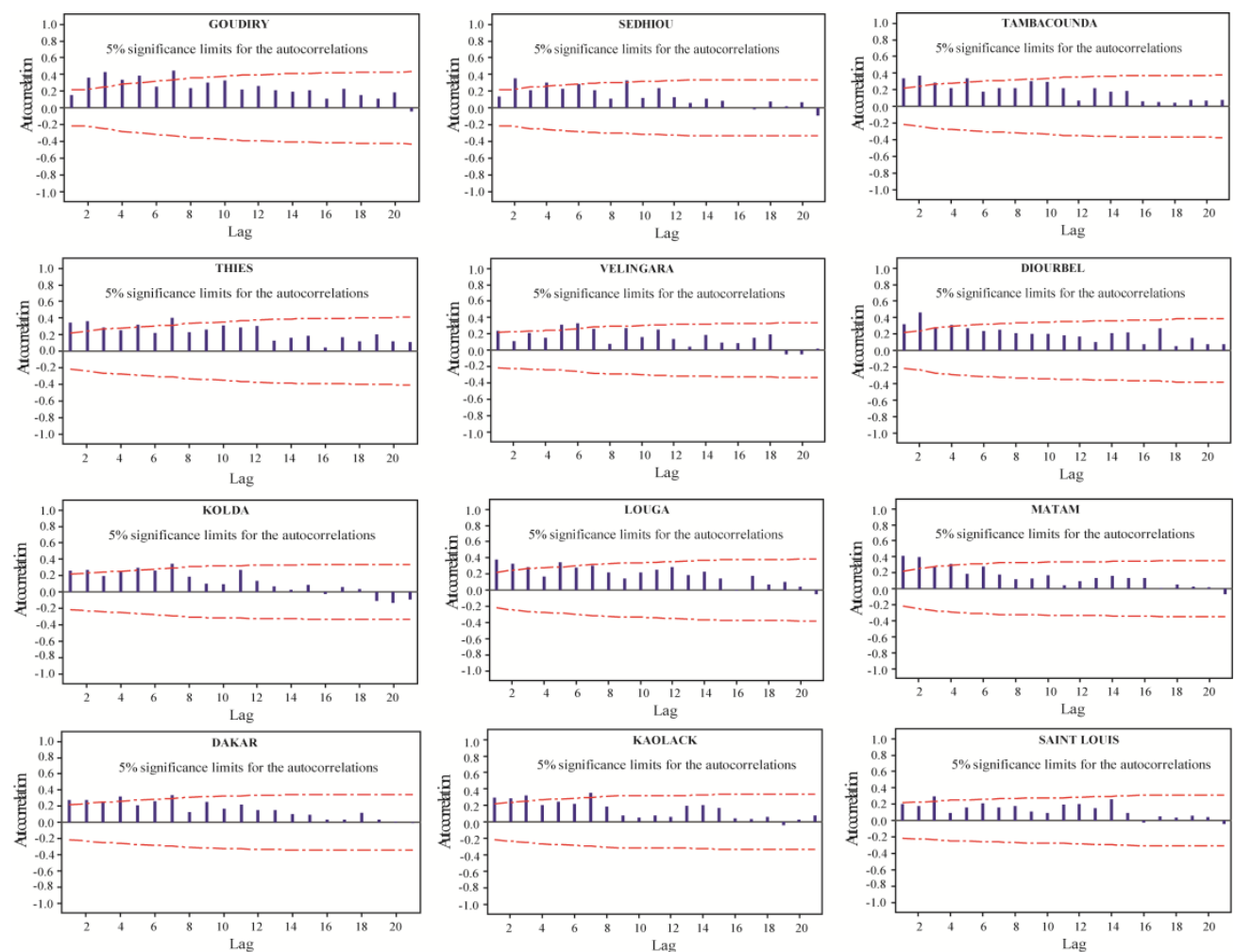

Figure 3: Serial correlation function of the annual precipitation series at some stations (The $95 \%$ confidence intervals are marked with dotted lines)

The trend analysis of the annual precipitation series after taking into account all significant serial correlations indicates decreasing trends at all stations for the period 1940 - 2013 except for Bakel which shows an increasing trend. For the period 1984 - 2013, all stations present an increasing trend; however, only $27 \%$ of the whole stations shows a significant upward trend.

The spatial distribution maps of the statistical Value $\mathrm{Z}$ of annual rainfall for the period 1940- 2013 (whole period) and 1984 - 2013 (last 30 years of our dataset) are illustrated in Figure 4. An upward trend is significant at $5 \%$ if $\mathrm{Z}$ is greater than 1.96 and downward trend is significant if $\mathrm{Z}$ is lesser than -1.96. As the Figure 4 shows, there is a general spatial pattern of downward for the period 1940-2013 except for the South East of the country which exhibits an upward trend around Bakel. This result is not recent because several studies (Bodian, 2014; Bodian et al., 2016) have shown this particularity of the station of Bakel presenting an upward trend but no clear explanation has given to that fact. It will be interesting to look the annual rainfall trend at the upper basin of the Senegal River in order to confirm whether or not it depends of its geographical position. The spatial repartition of the $\mathrm{Z}$ statistics show a significant negative trend over the area 
of study except a little part of the South eastern and western as well as some portions of the North east and West of the country. For the period 1984 2013, we have seen that there is, for the whole country, an upward trend; however, only few areas display a significant trend. These areas are mainly located in the Senegalese littoral part.
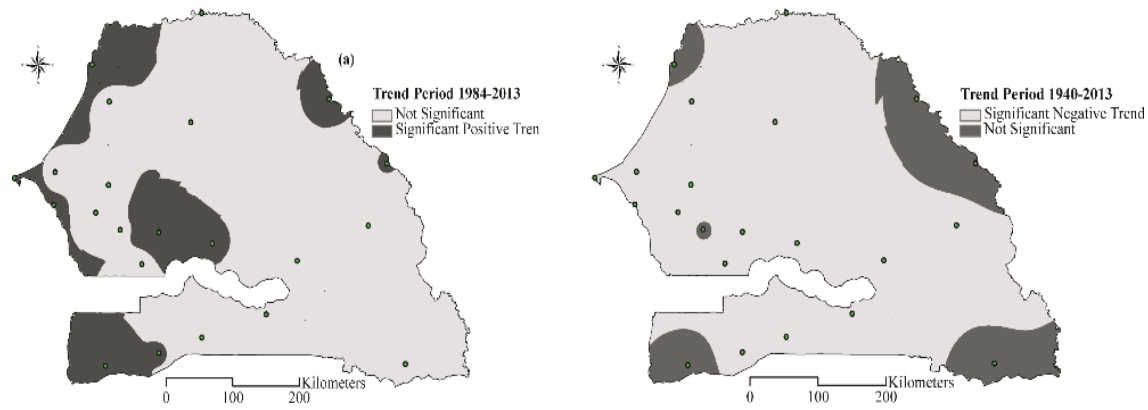

Figure 4: Spatial distribution of the statistics $\mathrm{Z}$ of the Mann-Kendall test for the annual rainfall (a) Period 1940-2013 (b) Period 1984 - 2013

The trend magnitude of annual rainfall is showed in Figure 5 (a) and (b) for the period 1940-2013 and 1984- 2013, respectively. During $1940-$ 2013, it is negative for the whole study area except for Bakel (1.34mm/year).

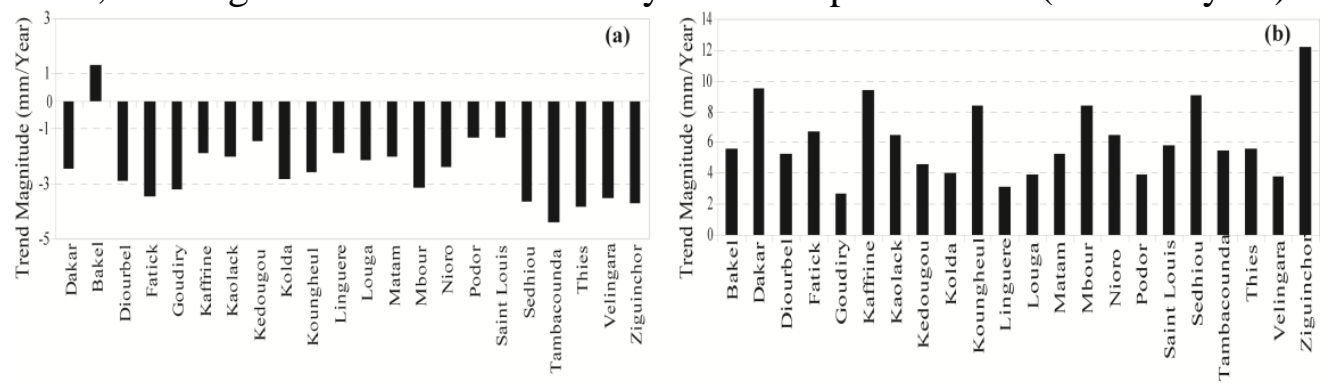

Figure 5: trend magnitude of the annual rainfall (a) Period 1940-2013 (b) Period 1984 - 2013

The trend magnitude varies between $-4.41 \mathrm{~mm} /$ year to $1.34 \mathrm{~mm} /$ year and the minimum value is observed at Tambacounda station (Eastern of the Country). This fact could participate to the depletion of groundwater as mentioned by Gajbhiye et al. (2015) who stated that decrease in rainfall will prompt greater extraction of ground water for irrigating crops and results in decline of groundwater level. For 1984 - 2013, the trend magnitude is positive for the whole country with values varying between $2.67 \mathrm{~mm} / \mathrm{year}$ at Goudiry and $12.2 \mathrm{~mm} /$ year at Ziguinchor. At the stations presenting significant positive trend (Dakar, Bakel, Kaffrine, Ziguinchor, Kougnhel, Matam, Saint Louis, Ziguinchor), the trend magnitude is greater than $5 \mathrm{~mm} /$ year. These results may show sign towards a progressive return on more favorable rainfall conditions as mentioned by Ozer et al. (2003). 
In general, the results show negative values for the period 1940-2013 except for Bakel and mainly positive values for 1984-2013, implying decreasing trend over the whole period while recent period exhibits an increasing trend.

The graph of time series and linear trends of annual rainfall at the stations with significant and no significant trends at chosen stations are presented in Figure 6, showing that annual rainfall decreased during 19402013 and increased for the period 1984-2013.

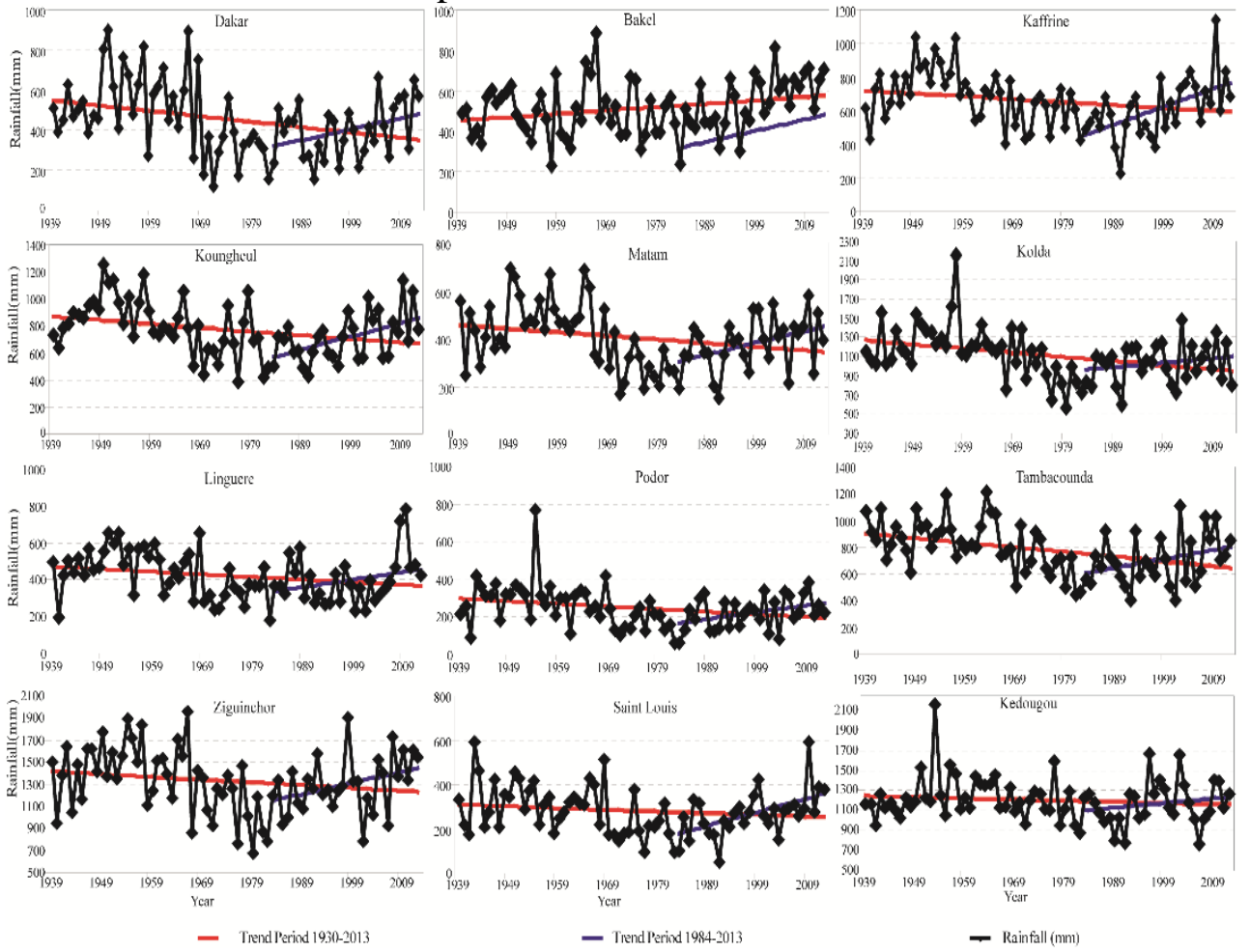

Figure 6: time series and linear trend of annual rainfall at chosen stations

These results confirmed those of some authors (Ozer et al., 2003 ; Niang et al., 2008 ; Hountondji et al., 2009 ; Ozer et al., 2009 ; Ouoba, 2013 ; Panthou et al., 2014) who suggested a return of wetted period since the 1990s. However, they contrasted the findings of several other authors (L'hote et al., 2002 ; Frappart et al., 2009 ; Lebel et Ali, 2009). Those authors divided Sahel in three parts (Western, Central, and Eastern) and noticed that the Eastern and Central Sahel exhibited a return of wetted period whereas the western part showed a different trend. The difference in their findings may be due to the difference in the period of study they had chosen. The relative change of the annual rainfall is presented in Figure 7 

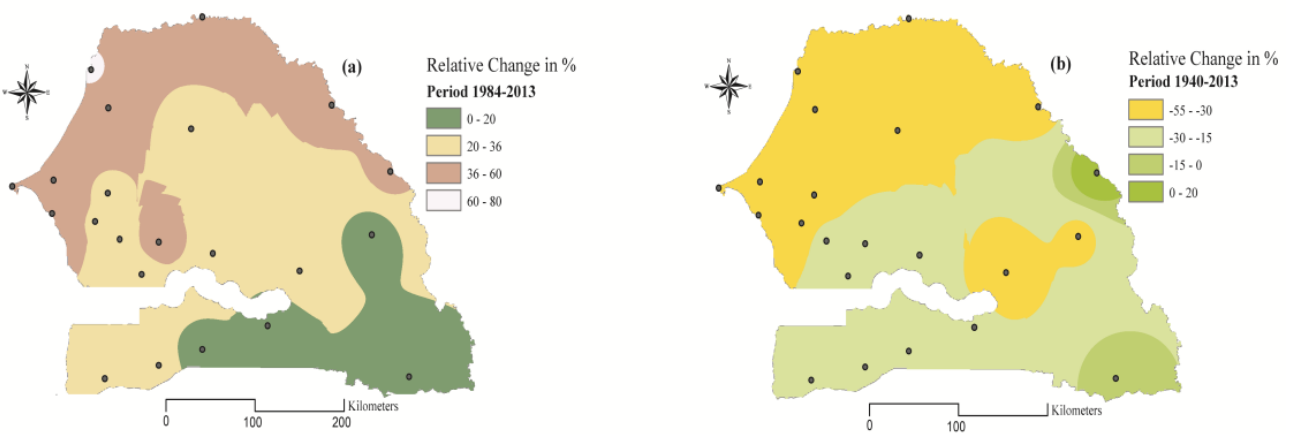

Figure 7: Relative change for the annual rainfall (a) Period 1984 - 2013 (b) Period 1940-2013

Maximum decreasing change in annual rainfall is 53.5\% (Station of Thies) for the period 1940-2013. For recent years (1984-2013), maximum increasing change in annual rainfall is $65 \%$ (Station of Saint Louis). During the period 1940-2013, the relative change is negatively highest in the regions presenting low average annual rainfall. For the period 1984-2013, the highest positive relative change is also observed in the regions presenting lower annual rainfall.

\section{Conclusion}

In this present study, the Mann-Kendall trend test and Theil-Sen's slope estimator were used to investigate the spatiotemporal trends of rainfall data from 22 stations in Senegal on the annual timescale for the period 19402013. The Z values of Mann-Kendall and Sen's slope tests presented both positive and negative trends in the study area depending on the chosen period. Over the whole 74 year periods, a negative trend in annual rainfall occurred at the 21 sites out of 22 . The spatial distribution of trend during the period 1940-2013 showed a significant negative trend in the whole study of area except small areas located at the extreme South Est and West as well as North East and West. There is an overall decrease in annual rainfall in Senegal during this period, while the period 1984-2013 exhibits an increase in annual rainfall. The strongest negative annual trend line slope was found to be $-4.43 \mathrm{~mm} /$ year at the Eastern part of the country, particularly at Tambacounda station for the period 1940-2013 and the highest positive annual trend was $+12.2 \mathrm{~mm} /$ year at Ziguinchor station (Southern of Senegal) for the period 1984-2013. The spatial distribution of relative change indicated that the higher value (65\%) happened in the northern of the country and coincided with the areas of minimal annual rainfall for the period 1984-2013. Concerning the period 1940 - 2013, the relative change was more pronounced in the North region, which decreased by $10 \%$ to more than $53.5 \%$. The analysis of rainfall data and findings will be useful for farmers and agricultural agencies and may play an important role in 
managing water resources and agriculture in Senegal in the context of climate change.

\section{Acknowledgements}

The authors thank the Senegal National Meteorology Agency (ANACIM) for providing the data used in this study.

\section{References:}

Ali, A. (2010). La variabilité et les changements climatiques au Sahel. Comprendre la situation actuelle de part l'observation. In : Le Sahel face aux changements climatiques. Enjeux pour un développement durable, Bulletin Mensuel du Centre Régional AGRHYMET, nº spécial, p. 17-20.

Arun, K.T., Murumkar, A. R. \& Arya, D. S. (2014). Long term spatial and temporal rainfall trends and homogeneity analysis inWainganga basin, Central India Weather and Climate Extremes (2014)50-61

Bodian, A. (2011). Approche par modélisation pluie-débit de la connaissance régionale de la ressource en eau : Application au haut bassin du fleuve Sénégal. Thèse de doctorat, Université Cheikh Anta Diop de Dakar (Sénégal), 288 p. URL : http://hydrologie.org/THE/BODIAN.pdf

Bodian, A. (2014). Caractérisation de la variabilité temporelle récente des précipitations annuelles au Sénégal (Afrique de l'Ouest). Physio-Géo Volume 8 (2014)

Bodian, A.,Ndiaye, O., \& Dacosta, A. (2016). Evolution des caractéristiques des pluies journalières dans le bassin du fleuve Sénégal : Avant et après rupture. Journal des Sciences Hydrologiques. http://dx.doi.org/10.1080/02626667.2014.950584.

Carbonnel, J.P. \& Hubert, P. (1985) - Sur la sécheresse au Sahel d'Afrique de l'Ouest. Une rupture climatique dans les séries pluviométriques du BurkinaFaso (ex Haute-Volta). Comptes Rendus de l'Académie des Sciences, Paris, Série II, vol. 301, n 13, p. 941-944.Climatol. doi:10.1007/s00704-014-11396

Du, J., Fang, J., Xu, W. \& Shi, P. (2013) Analysis of dry/wet conditions using the standardized precipitation index and its potential events over coastal regions of Iran. Theor Appl Climatol 103:401-412

Frappart, F., Hiernaux, P., Guichard, F., Mougin, E., Kergoat, L., Arjounin M... Lebel T. (2009). Rainfall regime across the Sahel band in the Gourma region, Mali. Journal of Hydrology, vol. 375, n 1-2,p. 128-142.

Gajbhiye, S., Meshram, C., Mirabbasi, R. \& Sharma, S. K. (2015). Trend analysis of rainfall time series for Sindh river basin in India. Theor Appl Climatol .DOI 10.1007/s00704-015-1529-4 
Gocic, M. \& Trajkovic, S. (2013). Analysis of changes in meteorological variables using Mann-Kendall and Sen's slopeestimator statistical tests in Serbia. Global and Planetary Change 100 (2013) 172-182

Gocic, M. \& Trajkovic S (2014) Analysis of trends in reference evapotranspiration data in a humid climate. Hydrol Sci J 59:165-180

Golian, S., Mazdiyasni, O., AghaKouchak, A. (2015). Trends in meteorological and agricultural droughts in Iran. Theoretical and Applied Climatology, 119(3-4), 679-688.

Hasan, Z., Akhter, S., Islam, M. (2014). Climate change and trend of rainfall in the south-east part of coastal Bangladesh. European Scientific Journal, 10(2).

Hountondji, Y.C., Sokpon, N, Nicolas, J. \& Ozer, P. (2009). Ongoing desertification processes in the sahelian belt of West Africa: an evidence from the rain-use efficiency. In : Recent advances in remote sensing and geoinformation processing for land degradation assessment, A. RÖDER et J. HILL édit., Édit. CRC Press, série ISPRS, vol. 8, p. 173-186.

Hubert, P. \& Carbonnel, J.P. (1987). Approche statistique de l'aridification de l'Afrique de l'Ouest. Journal of Hydrology, vol. 95, n 1, p. 165-183.

Hubert, P., Bader, J.C. \& Bendjoudi, H. (2007) - Un siècle de débits annuels du fleuve Sénégal. Journal des Sciences Hydrologiques, vol. 52, $\mathrm{n}^{\circ} 1$, p. 6873. URL : http://www.tandfonline.com/doi/pdf/10.1623/hysj.52.1.68.

Hubert, P., Carbonnel, J.P. \& Chaouche, A. (1989). Segmentation des séries hydrométéorologiques ; application à des séries de précipitations et de débits de l'Afrique de l'Ouest. Journal of Hydrology, vol. 110, n 3-4, p. 349-367.

Lamb, P.J. (1982). Persistence of sub-Saharan drought. Nature, vol. 299, p. 46-47.

Lebel, T. \& Ali, A. (2009). Recent trends in the Central and Western Sahel rainfall regime(1990-2007). Journal of Hydrology, vol. 375, n 1-2, p. 52-64. L'hôte, Y., Mahé, G., Somé, B. \& Triboulet, J.P. (2002). Analysis of a Sahelian annual rainfall index from 1896 to 2000; the drought continues. Hydrological Sciences Journal, vol. 47, n 4, p. 563-572

Liénou, G. (2007). Impacts de la variabilité climatique sur les ressources en eau et les transports de matières en suspension de quelques bassins versants représentatifs au Cameroun. Thèse de l'Université Montpellier II, 486 p. URL : http://hydrologie.org/THE/LIENOU.pdf.

Marofi, S., Sohrabi, MM., Mohammadi, K., Sabziparvar, AA. \& Zare, A.H. (2011) Investigation of meteorological extreme usefulness for drought/flood monitoring in Hunan Province, China. Stoch Environ Res Risk Assess 27:377-387

Mercy, I. C. (2015). Trend analysis of rainfall pattern in enugu state, nigeria. European Journal of Statistics and Probability Vol.3, No.3, pp.12-18, September 2015. 
Mondal, A., Kundu, S., Mukhopadhyay, A. (2012). Rainfall trend analysis by mann-kendall test: a case study of North-eastern part of cuttack district, Orissa. International Journal of Geology, Earth and Environmental Sciences ISSN: 2277-2081. 2012 Vol. 2 (1) January-April, pp.70-78.

Niang, A.J., Ozer, A. \& Ozer P. (2008). Fifty years of landscape evolution in South-WesternMauritania by means of aerial photos. Journal of Arid Environments, vol. 72, n² 2, p. 97-107.

Nicholson, S.E. (1986). The spatial coherence of African rainfall anomalies: interhemispheric teleconnections. Journal of Climate and Applied Meteorology, vol. 25, n 10, p. 1365-1381.

Nicholson, S.E., Somé, B. \& Koné, B. (1999) - An analysis of recent rainfall conditions in West Africa, including the rainy seasons of the 1997 El Niño and the 1998 La Niña years. Journal of Climate, vol. 13, n 14 , p. 2628-2640. OUOBA, A.P. (2013). Changements climatiques, dynamique de la végétation et perception paysanne dans le Sahel burkinabè. Thèse de Doctorat Unique, Université de Ouagadougou(Burkina Faso), 305 p.

Ozer, P., Erpicum, M., Demarée, G. \& Vandiepenbeck, M. (2003). The Sahelian drought may have ended during the 1990s. Hydrological Sciences Journal, vol. 48, n 3, p. 489- 492.

Ozer, P., Hountondji, Y.C. \& Laminou, M. O. (2009). Évolution des caractéristiques pluviométriques dans l'Est du Niger de 1940 à 2007. GeoEco-Trop, Revue de Géographie et d'Écologie Tropicale, vol. 33, n.s., p. 11 30. URL: http://orbi.ulg.ac.be/bitstream/2268/78267/1/Geo-EcoTrop_Ozer\%20et\%20al.pdf.

Panthou, G., Vischel, T. \& Lebel, T. (2014). Recent trends in the regime of extremerainfall in the Central Sahel. International Journal of Climatomogy.URL:http://onlinelibrary.wiley.com/doi/10.1002/joc.3984/abstr act.

Paturel, J.E., Servat, É., Lubès-Niel, H., Kouamé, B., Travaglio M., Lubès H., ... Masson, J.M. (1998) - Variabilité des régimes pluviométriques et hydrologiques en cette fin de siècle en Afrique de l'Ouest et centrale non sahélienne. Sud Sciences et Technologies, vol. 2, p. 44-52

Sene, S. \& Ozer, P. (2002). Évolution pluviométrique et relation inondations-événements pluvieux au Sénégal. Bulletin de la Société Géographique de Liège, vol. 42, p. 27-33.

Servat, É., Paturel, J. E., Lubès-Niel, H., Kouamé, B., Masson, J. M., Travaglio, M. \& Marieu B. (1999). De différents aspects de la variabilité de la pluviométrie en Afrique de l'Ouest et Centrale. Revue des Sciences de l'Eau, vol. 12, $\mathrm{n}^{\circ}$ 2, p. 363-387. URL: http://www.rse.inrs.ca/art/volume12/v12n2_363.pdf. 
Shepard, D. (1968). A two-dimensional interpolation function for irregularly-spaced data, Proc. 23rd National Conference ACM, ACM, 517524.

Sircoulon J. (1976). Les données hydro pluviométriques de la sécheresse récente en Afrique intertropicale. Comparaison avec les sécheresses "1913" et "1940". Cahiers ORSTOM, série Hydrologie, vol. XIII, n² 2, p. 75-174.

Tabari, H., Hosseinzadeh, T. P. (2011). Temporal variability of precipitation over Iran: 1966-2005. J Hydrol 396:313-320

Tabari, H., Taye, M. T. \& Willems, P. (2015). Statistical assessment of precipitation trends in the upper Blue Nile River basin Stoch Environ Res Risk Assess. DOI 10.1007/s00477-015-1046-0

UNEP (2015). Green Economy. Sector study: Water resource in Senegal. Working document 2015.

Yue, S., Pilon, P., Phinney, R. \& Cavadias, G. (2002). The influence of autocorrelation on the ability to detect trend in hydrological series. Hydrol Process 16:1807-1829

Zarenistanak, M., Dhorde, A. G. \& Kripalani, R. H. () Trend analysis and change point detection of annual and seasonal precipitation and temperature series over southwest Iran

Zhang, Q., Xu, CY., Tao, H., Jiang, T. \& Chen, YD. (2010). Climate changes and their impacts on water resources in the arid regions: a case study of the Tarim River basin, China. Stoch Environ Res Risk Assess 24:349-358 